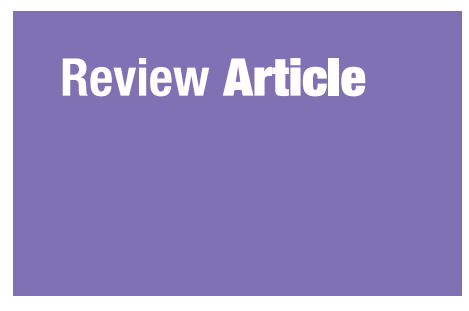

Submitted: 7 Jul 2018

Accepted: 13 Oct 2018

Online: 29 Aug 2019

\section{Understanding Myths in Pregnancy and Childbirth and the Potential Adverse Consequences: A Systematic Review}

\author{
Norain Ahmad, Sharifah Fazlinda Syed Nor, Faiz DaUd
}

Department of Community Health, Faculty of Medicine, Universiti Kebangsaan Malaysia, Kuala Lumpur, Malaysia

To cite this article: Ahmad N, Syed Nor SF, Daud F. Understanding myths in pregnancy and childbirth and the potential adverse consequences: a systematic review. Malays J Med Sci. 2019;26(4):17-27. https://doi.org/10.21315/ mjms2019.26.4.3

To link to this article: https://doi.org/10.21315/mjms2019.26.4.3

\begin{abstract}
The trend of choosing natural birth at home without proper supervision is gaining more attention and popularity in Malaysia. This is partly due to wrong beliefs of modern medical care. It prompts the need to explore further into other myths and wrong beliefs present in communities around the world surrounding pregnancy and childbirth that may lead to harmful consequences. A total of 25 literatures were selected and reviewed. The most reported wrong belief is the eating behaviour such as avoiding certain nutritious fruits besides eating saffron to produce fairer skinned babies which in fact contains high doses of saffron that may lead to miscarriage. The most worrying myth however, is that unregulated birth attendants such as doulas have the necessary knowledge and skills to manage complications in labour which may well end up in perinatal or even maternal death. Other myths suggested that modern medical care such as vaginal examinations and baby's heart monitoring in labour as unnecessary. A well-enforced health education programme by well-trained healthcare personnel besides sufficient number of antenatal care visits are needed to overcome these myths, wrong beliefs and practices. In conclusion, potential harmful beliefs and practices in pregnancy and childbirth are still abound in today's communities, not just in least developed and developing countries but also in developed countries. Women and children are two very vulnerable groups, therefore debunking myths and eliminating harmful practices should be one of a healthcare provider priority especially those in the primary care settings as they are the closest to the community.
\end{abstract}

Keywords: culture, perception, pregnancy, parturition, complications

\section{Introduction}

In February 2018, Malaysia was shocked by a heart-breaking news of a stillborn baby in the southern part of the country. Investigations into the death of the baby by the health authorities revealed that it was an outcome of a complicated homebirth, unfortunately this was not the first case. Since 2013, there were a number of cases of maternal and perinatal morbidity and mortality related to inappropriate homebirth. Despite continuous effort by the government to give the best medical and health services to the population, the trend of choosing natural birth at home without proper supervision which first originated in the West is gaining more attention and popularity in Malaysia.

Zielinski et al. (1) summarised in their study that homebirth rates in Western countries ranged from $0.1 \%$ in Sweden and up to $20 \%$ in Netherlands. Home birth became a favourable choice for pregnant women due to reasons such as women's right to choose their preferable environment, wanting to avoid medical intervention, e.g. episiotomy, induction of labour etc. and disagreement between mother and 
healthcare provider regarding birth plan (1). On the other hand, poor maternal and perinatal outcomes such as anaemia in pregnancy and low birth weight among new-borns are still significant now where food and healthcare are generally available and accessible. This similar situation is unfortunately seen in Malaysia as well.

Malaysian healthcare services is listed as one of the best in the world proven by the improvement in Maternal Mortality Ratio (MMR) trend since post-independence from 250 deaths per 100,000 live births to 28 deaths per 100,000 live births in 2010 (2). This remarkable pattern of MMR is the result of few main factors, such as cooperation and the commitment of the government to improve maternal and child health; feasibility and accessibility of maternal and child health services; improving family planning education and information and increasing access to healthcare facilities (3). Unfortunately, in 2012 the MMR adjusted to place of delivery was 296.4 deaths in 100,000 live births for homebirth compared to 19.5 and 18.6 for government and public health facilities, respectively.

There are many reasons as to why these women chose to deliver at home without a trained midwife supervision. However, based on the Theory of Reasoned Action, it is hypothesised that behaviour and action originated from beliefs mainly of the final outcome. Therefore, if these people knew that what they believe may lead to poor maternal or perinatal outcomes, they will less likely to remain steadfast to the beliefs and the behaviour related to it. This theory can be applied to health education programme by the health authorities in countering myths and wrong beliefs that may have been the norms for generations.

Most parts of the world have their own beliefs and practices in pregnancy that sometimes make the practices to be similar or different from one another. As reported by the United Nations, Convention on the Elimination of All Forms of Discrimination against Women, there are few cultural practices or beliefs that can affect women's health such as nutritional taboo during pregnancy that can cause malnutrition. Besides that, birth practice with traditional attendants is also a concern as traditional birth attendants are not trained in managing emergency situations (4).
Those are reported beliefs and practices known to the health authorities. Could this be the tip on the iceberg? What are other myths and pregnancy beliefs that can affect health negatively which we are unaware of? To answer these questions, a systematic review was done to identify the presence of myths and wrong beliefs in pregnancy and childbirth globally and to discuss the potential adverse outcomes related to them. The findings of this study will hopefully benefit policy makers and healthcare providers in understanding the current maternal and childbirth issues for future health programmes planning.

\section{Materials and Methods}

The search process for the articles was done from 15 Feb 2018 until 26 Mar 2018. We used four search engines; Google Scholar, Ovid, Scopus and PubMed. We used PRISMA checklist for the workflow of this systematic research. The keywords used were: i) myths in pregnancy, ii) pregnancy myths, iii) wrong beliefs in pregnancy, iv) home birth, v) lotus birth, vi) natural birth, vii) gentle birth, viii) hypnobirthing, ix) waterbirth, $\mathrm{x}$ ) traditional practice in pregnancy xi) culture in pregnancy, and xii) perception in pregnancy.

We chose all articles discussing myths or beliefs in pregnancy and childbirth worldwide that were published between Jan 2013 and Dec 2017. There were 56 peer-reviewed articles identified from the four databases and after removing duplicated articles, the total articles for screening became 55. Next, based on the exclusion criteria whereby articles that discussed myths that have no potential effects on health were excluded. Subsequently, the eligibility of the articles was evaluated based on the methodology especially on the validity of the study design. Therefore, the total final literatures reviewed in this study came to 25 journal articles (Figure 1). To ensure the understanding of contents of the articles, all 25 articles were read and reviewed twice, initially by the first reviewer, then the second. We came out with a summary of the characteristics of the articles selected based on the authors, year of publication, study population, study design and tools as well as the outcome measures. 
Review Article | Pregnancy and childbirth myths and its effects

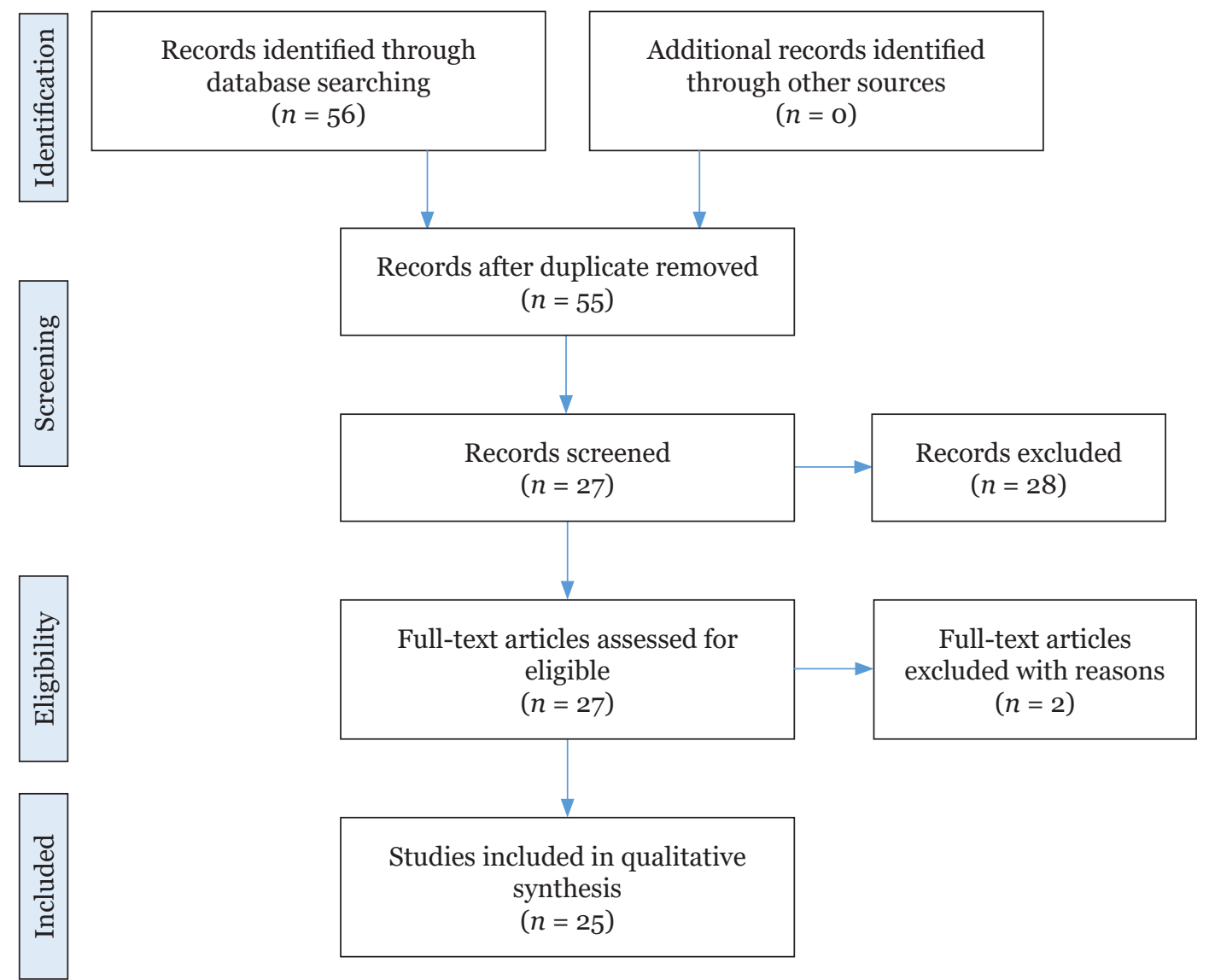

Figure 1. PRISMA flowchart of article selection

\section{Results}

This systematic review included 25 journal articles published from 2013 to 2017. The journal articles included two articles each from India, USA, Australia, Kenya, Nigeria, Malaysia and Ethiopia. One article each from Nepal, Tanzania, Pakistan, Philippines, Italy, Iran, Israel, Ghana, Bangladesh, Turkey and Laos. Nine of the studies used cross sectional design and the rest of the journal articles were qualitative studies. The studies included mostly used questionnaires, focused group discussions and in-depth interviews.

Table 1 outlined the characteristics of the journal articles in this review. A thematic analysis was done to all the myths found in the literatures reviewed, all of them can be categorised into these main themes; beliefs in eating behavior, beliefs in physical activity, beliefs in birthing process, beliefs in birth attendants and beliefs in placenta and umbilical cord.

\section{Beliefs in Eating Behaviour}

The most discussed about pregnancy and child birthing myths in the world belong to the eating behaviour theme. Thirteen of the articles reviewed involved myths in this category. Parmar et al. (5) in India reported that $31.7 \%$ of respondents believed that eating saffron results in fairer skin of the child. While saffron has its own beneficial medicinal effect, exposure to very high doses of saffron may increase the risk of miscarriage due to its uterotonic properties (6). At higher doses saffron has also been shown to cause embryonic malformation in animal's models and is therefore suggested to be avoided by pregnant women (6).

Certain fruits and vegetables are often believed to be bad for consumption in pregnancy. Two papers from India and one literature from Malaysia reported that papaya, jackfruit, bitter gourd and pineapple are among the fruits and vegetables believed to cause miscarriages (5, $7,8)$. One literature from Kenya reported that eating green leafy vegetables can cause hiccups 
Table 1. Characteristics of included studies

No. First author

1. Parmar et al. (5) Study Population

Women above 18 years old in rural Khodu, Surendranagar, India

2. Sharma et al. (43) Women with recent pregnancy and/or with a child under the age of 2, their mother-in-laws, husbands and health service providers in Nepal

3. Lennox et al. (12)

Pregnant women in Masaai, northern Tanzania

4. Marshall et al. (22) Pregnant women in rural

5. Burns (40)

6. Atif et al. (23)

7. Rigg et al. (25)

8. Bermio, Reotutar (20)

9. Bernhard et al. (27) Pregnant women in doula class in

10. Guggino et al. (10)

11. Roudsari et al. (35)

\section{Gogoi (8)}

13. Preis, Benyamini (26) western Michigan, USA

First trimester pregnant mother admitted to St. Anna Hospital of Turin, Italy

Pregnant women planning for home birth or women who gave birth at home in the last 3 years in Victoria, Australia

Patients who attended Combined Military Hospital, Peshawar Pakistan

Women and unregulated birth workers in Australia

Multigravida women of Ilocos Sur District Hospital, Phillipines

Pregnant women, women with previous childbirth experience, midwives, obstetricians and non pregnant women in Tonekabon, northern of Iran

Bodo community of NicChinakona, Assam, India

Pregnant women in Tel Aviv, Israel

\section{Study Design/ Tools Outcome}

Cross-sectional study, Taboos and questionnaire misconceptions in pregnancy

Qualitative, in-depth interview, focused group discussion

Beliefs around childbirth

Qualitative, semi-structured

Dietary pattern and individual interview, $24 \mathrm{~h}$ diet recall

Qualitative, questionnaire

Qualitative, in-depth interviews nutrition in pregnancy

Barriers to physical activity in pregnancy

Placenta beliefs and rituals

Cross-sectional study, questionnaire

Prevalence of myths in reproductive age women

Qualitative, in-depth interviews

Perception of women choosing unregulated birth worker

Cross-sectional study, questionnaire

High extend of cultural beliefs and practices among the women

Qualitative study, focused group discussion

Perception of current delivery intervention and beliefs in birthing mechanism

Cross-sectional study, semi-quantitative food-frequency questionnaire

Qualitative studyfocused, ethnographic semi-structured interviews and participant observations

Qualitativeethnographic study, interviews

Myths in nutritional intake in pregnancy

Myths and wrong beliefs regarding birth process

Myths and food taboos in pregnancy

Beliefs in birth process qualitative study, birth belief scalequestionnaire 
Table 1. (continued)

\begin{tabular}{|c|c|c|c|c|}
\hline No. & First author & Study Population & Study Design/ Tools & Outcome \\
\hline 14. & $\begin{array}{l}\text { Ezeama, Ezeamah } \\
\text { et al. (9) }\end{array}$ & $\begin{array}{l}\text { Women who had delivered babies } \\
\text { a year prior in Akin Yele LGA, } \\
\text { Oyo State Nigeria }\end{array}$ & $\begin{array}{l}\text { Quantitaive and } \\
\text { qualitative study, } \\
\text { questionnaire and } \\
\text { focused group } \\
\text { discussion }\end{array}$ & $\begin{array}{l}\text { Atitude and } \\
\text { sociocultural pactice } \\
\text { during pregnancy }\end{array}$ \\
\hline 15 . & Otoo et al. (13) & $\begin{array}{l}\text { Pregnant women and women who } \\
\text { delivered within } 12 \text { months prior } \\
\text { in Shama district of the western } \\
\text { region of Ghana }\end{array}$ & $\begin{array}{l}\text { Qualitative, } \\
\text { focussed group } \\
\text { discussion and in- } \\
\text { depth interview }\end{array}$ & $\begin{array}{l}\text { Traditional practices } \\
\text { associated with } \\
\text { pregnancy and } \\
\text { childbirth }\end{array}$ \\
\hline 16. & Sarker et al. (30) & $\begin{array}{l}\text { Stakeholders, healthcare workers } \\
\text { and women in Sunamganj district } \\
\text { of Bangladesh }\end{array}$ & $\begin{array}{l}\text { Qualitative cross- } \\
\text { sectional, } \\
\text { in-depth interview }\end{array}$ & $\begin{array}{l}\text { Preference of } \\
\text { home delivery with } \\
\text { traditional birth } \\
\text { attendants and the } \\
\text { associated factors }\end{array}$ \\
\hline 17. & Riang'a et al. (17) & $\begin{array}{l}\text { Pregnant and postnatal women in } \\
\text { Kalenjin, Kenya }\end{array}$ & $\begin{array}{l}\text { Qualitative, } \\
\text { semi-structured } \\
\text { interview }\end{array}$ & $\begin{array}{l}\text { Restricted and } \\
\text { recommended food in } \\
\text { pregnancy }\end{array}$ \\
\hline 18. & Ekwochi et al. (18) & $\begin{array}{l}\text { Women who had carried at least } \\
\text { one pregnancy to term in Enugu } \\
\text { south east Nigeria }\end{array}$ & $\begin{array}{l}\text { Qualitative cross- } \\
\text { sectional, } \\
\text { questionnaire }\end{array}$ & $\begin{array}{l}\text { Food avoidance and the } \\
\text { associated factors }\end{array}$ \\
\hline 19. & $\begin{array}{l}\text { Taşçı-Duran, Sevil } \\
\text { (16) }\end{array}$ & $\begin{array}{l}\text { Pregnant women (15-49 years } \\
\text { old) in Bornova Izmir, Turkey }\end{array}$ & $\begin{array}{l}\text { Qualitative } \\
\text { ethnonursing, } \\
\text { in-depth face-to- } \\
\text { face semi-structured } \\
\text { interview }\end{array}$ & $\begin{array}{l}\text { Health behaviours } \\
\text { during prenatal period }\end{array}$ \\
\hline 20. & $\begin{array}{l}\text { Mohamad, Chong } \\
\text { (7) }\end{array}$ & $\begin{array}{l}\text { Malay pregnant women in Kuala } \\
\text { Lumpur, Malaysia }\end{array}$ & $\begin{array}{l}\text { Cross-sectional, } \\
\text { face-to-face } \\
\text { questionnaire }\end{array}$ & $\begin{array}{l}\text { Prevalence and types } \\
\text { of food taboos and its } \\
\text { reason for avoidance }\end{array}$ \\
\hline 21. & Zepro (14) & $\begin{array}{l}\text { Pregnant women in Shashemene } \\
\text { district of Ethiopia }\end{array}$ & $\begin{array}{l}\text { Cross-sectional } \\
\text { questionnaire }\end{array}$ & $\begin{array}{l}\text { Prevalence of taboos/ } \\
\text { misconceptions in } \\
\text { pregnancy and its } \\
\text { associated factors }\end{array}$ \\
\hline 22. & Law, Soon (33) & $\begin{array}{l}\text { Antenatal and postnatal mothers } \\
\text { admitted to Hospital Universiti } \\
\text { Sains Malaysia, Kelantan, } \\
\text { Malaysia }\end{array}$ & $\begin{array}{l}\text { Cross-sectional } \\
\text { interview, structured } \\
\text { questionnaire }\end{array}$ & $\begin{array}{l}\text { Prevalence and } \\
\text { description of herbal } \\
\text { medicine usage in } \\
\text { pregnancy }\end{array}$ \\
\hline 23. & Roro et al. (28) & $\begin{array}{l}\text { Women and their men/partners } \\
\text { who delivered past } 2 \text { years in } \\
\text { Butajira, Ethiopia }\end{array}$ & $\begin{array}{l}\text { Qualitative, } \\
\text { focussed group } \\
\text { discussion }\end{array}$ & $\begin{array}{l}\text { Reasons for not } \\
\text { choosing to deliver at } \\
\text { health facilities }\end{array}$ \\
\hline 24. & $\begin{array}{l}\text { Sychareun et al. } \\
(29)\end{array}$ & $\begin{array}{l}\text { Postnatal women, husbands, } \\
\text { mothers, traditional birth } \\
\text { attendants, head villagers, Lao } \\
\text { Women's Union members and } \\
\text { healthcare workers in central } \\
\text { Laos }\end{array}$ & $\begin{array}{l}\text { Qualitative } \\
\text { interview, focussed } \\
\text { group discussion }\end{array}$ & $\begin{array}{l}\text { Cultural beliefs and } \\
\text { practices surrounding } \\
\text { pregnancy, antenatal } \\
\text { and postpartum care }\end{array}$ \\
\hline 25 . & Okafor et al. (15) & $\begin{array}{l}\text { Women }(15-45 \text { years old) who } \\
\text { delivered } 2 \text { years prior to study in } \\
\text { southwest Nigeria }\end{array}$ & $\begin{array}{l}\text { Qualitative, focussed } \\
\text { group discussion }\end{array}$ & $\begin{array}{l}\text { Determinants and } \\
\text { reasons of choosing } \\
\text { orthodox versus } \\
\text { unorthodox care }\end{array}$ \\
\hline
\end{tabular}


and gasping in babies during breastfeeding (9). Whereas in Italy, sugar is believed to be the cure for dizziness and weakness during pregnancy (10). In a study of dietary patterns and development of gestational diabetes mellitus (GDM), Shin et al. (11) reported that higher consumption of refined grains, fat, added sugar and low intake of fruits and vegetables imposed higher odds for developing GDM.

The Maasai women in Tanzania and Ghana generally restrict food in pregnancy to avoid having bigger babies and difficult labour $(12,13)$ whilst women in Shashemene in Ethiopia avoid nutritious food such as linseed, honey, milk and yoghurt (14). Whereas women in southwest Nigeria consumed herbal concoction to have smaller babies and ease delivery (15). Women in Turkey avoid fish for fear of having fish-mouthed babies and liver for fear of having babies with stained skin (16). Women in south-eastern Nigeria and a rural district in Kenya avoided snails, bushmeat and eggs which were their main daily source of protein also due to fear of big babies and prolonged labour $(17,18)$. As a result, these women take very little food on top of their pre-existing nausea and loss of appetite. They are often left feeling tired and malnourished and subsequently risk having low birth weight babies due to insufficient calorie intake. Choudhary et al. (19) reported that daily consumption of less than $2000 \mathrm{kcal}$ is associated with higher risk for low birth weight babies.

On the other hand, a common myth in pregnancy that may have an opposite effect which is eating for two. This was reported in the papers from Philippines and Italy (10, 20). Maternal obesity and increased weight gain during pregnancy that may result from this particular myth are found to be associated with GDM, gestational hypertension, pre-eclampsia, large for gestational age babies and childhood obesity (21). It is also a known risk factor for deep vein thrombosis which can be fatal due to pulmonary embolism.

\section{Beliefs in Physical Activity}

Three of the papers reviewed reported myths involving physical activity during pregnancy. Marshall et al. (22) reported that in a rural community in south-eastern USA, physical activity among pregnant women is generally not undertaken due to the belief that daily life activities provide sufficient exercises. Some thought that rest is more important than physical activity, while others believed that physical activity poses safety risks to both mother and baby (22). Unlike pregnant women of Maasai in Tanzania, they will steadily increase their workload of daily chores through the second and third trimester up to the point of exhaustion and miss their antenatal check-ups, in preparation for their postnatal period in which they will stay in their homes for three months (12). Whereas in Pakistan, Atif et al. (23) reported that $76.4 \%$ of respondents believed that mild to moderate weight lifting causes miscarriage.

Center for Disease Control and Prevention (CDC) stated that physical activity is good for overall health of pregnant and postpartum women since it also improves mood in the postpartum period. The recommended amount of physical activity by the 2008 Physical Activity Guidelines for American adults is at least 150 min per week of moderate-intensity exercises such as brisk walking during and after pregnancy in which it is best to spread the activity throughout the week whereas healthy women who already do vigorous-intensity activity can continue doing so as long as they stay healthy throughout their pregnancy (24). It does not pose any safety risks neither does it causes low birth weight babies, early delivery or miscarriage. It is a known fact that immobility is one of the main risk factors for deep vein thrombosis, therefore pregnant women are encouraged to be as physically active.

\section{Beliefs in Birthing Process}

Eleven of the reviewed literatures discussed about beliefs that fall under the birthing process theme. Three of the papers reported were from Australia, USA and Israel that stated that birth is a natural event and modern medical care during delivery interrupts natural birth process (25-27). In addition, respondents who preferred natural birth at home perceived modern medical care and interventions such as vaginal examinations, baby's heart monitoring, injections and painkillers as unnecessary (25). Women in south central Ethiopia avoided hospital delivery for fear of having minor or major operations such as caesarean sections (28). Whereas women in rural Laos and southwest Nigeria believed that attending antenatal care and giving birth at a health facility is needed only when they felt that they are not healthy $(15,29)$. Some papers reported that modern medical care during delivery is seen as disrespecting and disempowering of women in labour $(25,27,30)$. It was also reported that some people placed 
comfort as their top priority and often relate comfort to safety $(25,30)$. This belief is a concern since even among low risk pregnant women who have been assessed and allowed to deliver at home under a midwife supervision, $40 \%$ of them ended up being referred to hospital due to unexpected complications in labour (31).

In Israel, there are two main beliefs about the birthing process; belief that birth is a medical process and belief that birth is a natural process (26). Those who believed birth is a natural process had similar ideation about natural birth as in the rest of the world that it is empowering of women and should be allowed to proceed at its own pace (26). In a case control study of intrapartum stillbirth and livebirth in Nepal, it was found that there was an increased risk of intrapartum stillbirth when fetal heart rate was inadequately monitored and when the progress of labour was not monitored using a partogram (32). Therefore, if labour is allowed to progress at its own pace without any intervention, there is an increased likelihood of having poor perinatal outcomes. In contrast, a paper from Malaysia reported that most respondents used herbal medicine to facilitate labour (33) which may risk precipitating labour and postpartum haemorrhage.

In regards to mode of delivery, one paper from Pakistan reported that respondents preferred vaginal delivery over caesarean section due to the belief that pregnancy weight gain persists longer after caesarean section (23). This may not be totally true as weight loss after delivery is much more related to the amount of physical activity and most importantly the dietary pattern practiced by these women. Exclusive breastfeeding is also found to increase weight loss post-delivery (34). On the other hand in Iran, the mode of delivery can be perceived as a status symbol, whereby normal vaginal delivery is seen as a low cost mode of delivery whereas caesarean section is preferred as it is seen as a prestigious mode of delivery (35). This is in alignment with the commonly used expression 'too posh to push'. It may cause an increased rate of unnecessary caesarean sections which may indirectly increase the incidence of maternal morbidity and mortality. In a Swedish case control study, Karlström et al. (36) reported that maternal complications occurred more frequently among women undergoing caesarean section. Whereas in Brazil, it was found that the risk of postpartum maternal death was almost three-fold higher with caesarean than vaginal delivery (37). This proves that caesarean section is not superior to normal vaginal delivery unless indicated.

\section{Beliefs in Birth Attendants}

Three articles were found to discuss about beliefs in birth attendants. A paper from Australia reported on reasons why women chose unregulated birth worker over certified trained midwives. These women believe unregulated birth worker provides the best of both worlds which is support for physiological paradigm of birth and birth care that made them feel safe (25). For them, births at home by registered midwives is an introduction of hospital policies, rules and regulation into women's homes which are very strict and rigid (25). Healthcare workers in health facilities were perceived to be not welcoming towards them (28). Some also believed that a doula or traditional birth attendant has the necessary knowledge and skills to anticipate and manage complications in labour $(25,28,30)$. This is a wrong perception because they are not trained to perform clinical and medical tasks therefore would not know how to handle complications.

Most obstetric complications could only be prevented or managed if women had access to a skilled birth attendant during childbirth. Increment of coverage of skilled birth attendants during delivery may have contributed to the decline of maternal mortality from 1990 to 2015 globally according to WHO (38), especially in Sri Lanka, Malaysia, Thailand, Egypt, Honduras and Bangladesh (39).

\section{Beliefs in Placenta and Umbilical Cord}

There were four papers discussing about beliefs in placenta and umbilical cord. A paper from Australia found that respondents chose to leave the placenta intact (lotus birth) after delivery because they believed that lotus birth is the baby's right and cutting the cord is seen as to take control over something that is not yours (40). They also believed that there is a spiritual connection between the baby and the placenta (40). Royal College of Obstetrics and Gynaecologists (RCOG) does not recommend umbilical non-severance or lotus birth because there is a risk of infection spreading to a baby since the placenta contains blood (41). Besides the practice of lotus birth, Burns (40) reported that some of the respondents consumed their placenta because they believed that it has 
beneficial medicinal properties. A systematic review regarding placentophagy concluded there is no strong evidence of the beneficial effect of consuming placenta and further studies are needed especially on the health effects of placentophagy on humans (42).

Respondents from Nepal and Laos practiced cutting the umbilical cord with a bamboo, razor or sickle and then applying cooking oil, ghee, toothpaste or ash $(29,43)$. Cutting the cord with a dirty apparatus such as a razor blade or sickle increases the likelihood of contracting neonatal tetanus in which WHO estimated 34,019 newborns died from neonatal tetanus globally in 2015 (44). Another belief related to placenta is that inserting a piece of cloth into women's mouth to induce vomiting (gag reflex) or blowing air into a bottle can expel placenta $(13,43)$. Retained placenta is an obstetrical emergency that needs urgent medical attention. If it is not treated properly the woman may suffer from postpartum haemorrhage and subsequently death.

\section{Discussion}

Cultural beliefs and practices in pregnancy and childbirth are still relevant in communities today especially in the rural setting. It encompasses many aspects of pregnant women's daily life activities from eating behaviour up to the process and mode of delivery. As social media has become significant in most parts of the world, these myths and wrong beliefs can easily be shared and spread to other parts of the world. However not all these beliefs are culturally related in fact, some of these beliefs are due to peer pressure, poor knowledge or ignorance. Whichever way it is, this issue can be overcome by implementing a well enforced health education programme which should be instated early and well throughout the course of a pregnancy.

WHO encourages early antenatal booking and sufficient antenatal visits from then on. Previously, the recommended number of antenatal visits is at least four times before delivery. However in 2016, it was changed to eight visits in which the first contact should be at 12 weeks then the subsequent visits will be at $20,26,30,34,36,38$ and 40 weeks' gestation (45). Higher frequency of antenatal contacts can increase the opportunity for healthcare providers to build good rapport and give sufficient advice and valuable knowledge that may guide these women in making the right decisions in pregnancy and childbirth for example in choosing the right food to consume or avoid as well as choosing the best place or mode of delivery.

Healthcare personnel on the other hand should have the right attitude, skills and knowledge to educate these women as soft skills is one of the main areas that is often lacking among healthcare workers. As a result, these women are easily influenced by their peers and family members more than the medical experts themselves. In addition, healthcare providers should also be accommodating by involving pregnant women especially in coming up with the agreed birth plan as much as they can. However, to end unsupervised homebirth, supervised natural birth services may need to be established in our healthcare facilities with proper guidelines and standard operating procedures in place. Besides that, there should be adequate resources and training of staffs before introducing this new policy.

\section{Conclusion}

From this systematic review, it was found that myths and wrong beliefs in pregnancy and childbirth still exist not just in the least developed or developing countries, but also in the developed countries all around the world. Women and children are two very vulnerable groups in the community and ensuring the wellbeing of these groups have always been the main agenda for many health organisations in the world. Due to this fact, debunking myths and eliminating practices that may have potential adverse health effects in these groups should be one of a healthcare provider priority especially those in the primary care settings as they are the front liners closest to the community.

\section{Acknowledgements}

We would like to express our gratitude to all individuals who have directly or indirectly provided assistance and technical help to the completion of this review article.

\section{Conflict of Interest}

None. 
Review Article | Pregnancy and childbirth myths and its effects

\section{Funds}

None.

\section{Authors' Contributions}

Conception and design: NA

Analysis and interpretation of the data: NA, SFSN

Drafting of the article: NA, SFSN

Critical revision of the article for important intellectual content: FD

Final approval of the article: FD

\section{Correspondence}

Dr Faiz Daud

MBBS (International Islamic University Malaysia),

MPH (University of Sydney)

Department of Community Health,

Faculty of Medicine,

Universiti Kebangsaan Malaysia, Jalan Yaacob Latif, 56000 Batu 9 Cheras,

Kuala Lumpur, Malaysia.

Tel: +603 91455888/5887

Fax: +603 91456670

E-mail: faizdaud@ppukm.ukm.edu.my

\section{References}

1. Zielinski R, Ackerson K, Low LK. Planned home birth: benefits, risks, and opportunities. Int $J$ Womens Health. 2015;7:361.

2. Yadav H. A review of maternal mortality in Malaysia. International e-Journal of Science, Medicine \& Education. 2012;6(Suppl 1):S142S151.

3. United Nations in Malaysia. Malaysia achieving the millenium goals sucessess and challenges. Kuala Lumpur, Malaysia: United Nations Country Team, Malaysia; 2005. 22 p.

4. United Nations Office of the High Commissioner for Human Rights. Fact Sheet No. 23, Harmful traditional practices affecting the health of women and children; Kuala Lumpur: United Nations Country Team Malaysia;1995.

5. Parmar A, Khanpara H, Kartha G. A study on taboos and misconceptions associated with pregnancy among rural women of Surendranagar district. Healthline Global Journal of Healthcare. 2013;4(2): 4 .
6. Bostan HB, Mehri S, Hosseinzadeh H. Toxicology effects of saffron and its constituents: a review. Iran J Basic Med Sci. 2017;20(2):110.

7. Mohamad M, Chong YL. Food taboos of malay pregnant women attending antenatal check-up at the maternal health clinic in Kuala Lumpur. Integrative Food, Nutrition and Metabolism. 2016;3(1):6. https://doi.org/10.15761/ IFNM.1000140

8. Gogoi M. Taboos and myths associated with pregnancy among the Bodos of Assam. International Journal for Innovative Research in Multidisciplinary Field. 2016;2(10):4.

9. Ezeama MC, Ezeamah I. Attitude and sociocultural practice during pregnancy among women in Akinyele L. G. A. of Oyo State, Nigeria. Journal of Research in Nursing and Midwifery. 2014;3(1):7.

10. Guggino A, Barbero S, Ponzo V, Viora E, Durazzo M, Bo S. Myths about nutrition in pregnancy. Journal of Obstetrics and Gynaecology. 2016;36(7):964-965. https://doi.org/10.3109/01 443615.2016.1168372

11. Shin D, Lee K, Song W. Dietary patterns during pregnancy are associated with risk of gestational diabetes mellitus. Nutrients. 2015;7(11):5472. https://doi.org/10.3390/nu7115472

12. Lennox J, Petrucka P, Bassendowski S. Eating practices during pregnancy: perceptions of select Maasai women in northern Tanzania. Global Health Research and Policy. 2017;2(1):9. https:// doi.org/10.1186/s41256-017-0028-9

13. Otoo P, Habib H, Ankomah A. Food prohibitions and other traditional practices in pregnancy: a qualitative study in western region of Ghana. Advances in Reproductive Sciences. 2015;3(3):9. https://doi.org/10.4236/arsci.2015.33005

14. Zepro NB. Food taboos and misconceptions among pregnant women of Shashemene district, Ethiopia, 2012. Science Journal of Public Health. 2015;3(3):7. https://doi.org/10.11648/j. sjph.20150303.27

15. Okafor IP, Sekoni AO, Ezeiru SS, Ugboaja JO, Inem V. Orthodox versus unorthodox care: a qualitative study on where rural women seek healthcare during pregnancy and childbirth in southwest, Nigeria. Malawi Medical Journal: the Journal of Medical Association of Malawi. 2014;26(2):45-49. 
16. Taşçı-Duran E, Sevil U. A Comparison of the prenatal health behaviors of women from four cultural groups in Turkey: an ethnonursing study. Nurs Sci Q. 2013;26(3):257-266. https://doi. org/10.1177/0894318413489180

17. Riang'a RM, Broerse J, Nangulu AK. Food beliefs and practices among the Kalenjin pregnant women in rural Uasin Gishu County, Kenya. $J$ Ethnobiol Ethnomed. 2017;13(1):29. https://doi. org/10.1186/s13002-017-0157-8

18. Ekwochi U, Osuorah $\mathrm{CD}, \mathrm{Ndu} \mathrm{IK}$, Ifediora $\mathrm{C}$, Asinobi IN, Eke CB. Food taboos and myths in south eastern Nigeria: the belief and practice of mothers in the region. J Ethnobiol Ethnomed. 2016;12(7):1-6. https://doi.org/10.1186/s13002016-0079-x

19. Choudhary A, Choudhary A, Tiwari S, Dwivedi R. Factors associated with low birth weight among newborns in an urban slum community in Bhopal. Indian Journal of Public Health. 2013;57(1):20. https://doi.org/10.4103/o019-557X.111362

20. Bermio JB, Reotutar LP. Beliefs and practices during pregnancy, labor and delivery, postpartum and infant care of women in the second district of Ilocos Sur, Phillippines. International Journal of Scientific \& Engineering Research. 2017;8(9):11.

21. Gaillard R, Durmuş B, Hofman A, Mackenbach JP, Steegers EA, Jaddoe VW. Risk factors and outcomes of maternal obesity and excessive weight gain during pregnancy. Obesity. 2013;21(5):1046-1055. https://doi.org/10.1002/ oby. 20088

22. Marshall ES, Bland H, Melton B. Perceived barriers to physical activity among pregnant women living in a rural community. Public Health Nurs. 2013;30(4):361-369. https://doi. org/10.1111/phn.12006

23. Atif K, Naqvi SS, Hassan Naqvi SA, Ehsan K, Niazi SA, Javed A. Reproductive health issues in Pakistan; do myths take precedence over medical evidence? The Journal of the Pakistan Medical Association. 2017;67(8):1232-1237.

24. Centers for Disease Control and Prevention. Healthy pregnant or post partum women. Atlanta USA: Centers for Disease Control and Prevention; 2015 [updated 4 June 2015]. Available from: https://www.cdc.gov/physicalactivity/basics/ pregnancy/index.htm
25. Rigg EC, Schmied V, Peters K, Dahlen HG. Why do women choose an unregulated birth worker to birth at home in Australia: a qualitative study. BMC Pregnancy Childbirth. 2017;17(1):99. https://doi.org/10.1186/s12884-017-1281-o

26. Preis H, Benyamini Y. The birth beliefs scale-a new measure to assess basic beliefs about birth. $J$ Psychosom Obstet Gynaecol. 2017;38(1):73-80. https://doi.org/10.1080/0167482X.2016.1244180

27. Bernhard C, Zielinski R, Ackerson K, English J. Home birth after hospital birth: women's choices and reflections. Journal of Midwifery \& Women's Health. 2014;59(2):16o-166. https://doi. org/10.1111/jmwh.12113

28. Roro MA, Hassen EM, Lemma AM, Gebreyesus $\mathrm{SH}$, Afework MF. Why do women not deliver in health facilities: a qualitative study of the community perspectives in south central Ethiopia? BMC Res Notes. 2014;7(1):556. https://doi.org/10.1186/1756-0500-7-556

29. Sychareun V, Somphet V, Chaleunvong K, Hansana V, Phengsavanh A, Xayavong S, et al. Perceptions and understandings of pregnancy, antenatal care and postpartum care among rural Lao women and their families. BMC Pregnancy Childbirth. 2016;16(1):245. https://doi. org/10.1186/s12884-016-1031-8

30. Sarker BK, Rahman M, Rahman T, Hossain J, Reichenbach L, Mitra DK. Reasons for preference of home delivery with traditional birth attendants (TBAs) in rural Bangladesh: a qualitative exploration. PLoS One. 2016;11(1):e0146161. https://doi.org/10.1371/journal.pone.0146161

31. Md Noor MR. Natural birth. 2015. [cited 2018]. Available from: https://dribnusina.blogspot. my/2015/05/kelahiran-semulajadi-natural-birth. html

32. Ashish K, Wrammert J, Clark RB, Ewald U, Målqvist M. Inadequate fetal heart rate monitoring and poor use of partogram associated with intrapartum stillbirth: a case-referent study in Nepal. BMC Pregnancy Childbirth. 2016;16(1):233. https://doi.org/10.1186/s12884016-1034-5

33. Law KS, Soon LK. Herbal medicines: Malaysian women's knowledge and practice. $J$ Evid Based Complementary Altern Med. 2013;2013:1-10. https://doi.org/10.1155/2013/438139 
Review Article | Pregnancy and childbirth myths and its effects

34. Jarlenski MP, Bennett WL, Bleich SN, Barry CL, Stuart EA. Effects of breastfeeding on postpartum weight loss among US women. Prev Med. 2014;69:146-150. https://doi.org/10.1016/j. ypmed.2014.09.018

35. Roudsari RL, Zakerihamidi M, Khoei EM. Sociocultural beliefs, values and traditions regarding women's preferred mode of birth in the North of Iran. International Journal of Community Based Nursing and Midwifery. 2015;3(3):165.

36. Karlström A, Lindgren H, Hildingsson I. Maternal and infant outcome after caesarean section without recorded medical indication: findings from a Swedish case-control study. An International Journal of Obstetrics \& Gynaecology. 2013;120(4):479-486. https://doi. org/10.1111/1471-0528.12129

37. Esteves-Pereira AP, Deneux-Tharaux C, Nakamura-Pereira M, Saucedo M, Bouvier-Colle M-H, do Carmo Leal M. Caesarean delivery and postpartum maternal mortality: a populationbased case control study in Brazil. PloS One. 2016;11(4):e0153396. https://doi.org/10.1371/ journal.pone.0153396

38. World Health Organization. Skilled attendants at birth. Geneva: WHO; 2018. Available from: http://www.who.int/gho/maternal_health/ skilled_care/skilled_birth_attendance_text/en/

39. Blaauw D. Skilled birth attendance in the post2015 maternal health development agenda: knowledge translation network Africa (KTNet); 2015. Available from: http://ktnetafrica.net/ blog/skilled-birth-attendance-post-2015-maternalhealth-development-agenda-dr-duane-blaauw
40. Burns E. More than clinical waste? placenta rituals among Australian home-birthing women. $J$ Perinat Educ. 2014;23(1):41-49. https://doi. org/10.1891/1058-1243.23.1.41

41. Royal College of Obstetricians and Gynaecologists. RCOG statement on umbilical non-severance or "lotus birth". London: Royal College of Obstetricians and Gynaecologists; 2013. Available from: https://www.rcog.org. uk/en/news/rcog-statement-on-umbilical-nonseverance-or-lotus-birth

42. Coyle CW, Hulse KE, Wisner KL, Driscoll KE, Clark CT. Placentophagy: therapeutic miracle or myth? Arch Womens Ment Health. 2015;18(5):673-680. https://doi.org/10.1007/ s00737-015-0538-8

43. Sharma S, van Teijlingen E, Hundley V, Angell C, Simkhada P. Dirty and 40 days in the wilderness: eliciting childbirth and postnatal cultural practices and beliefs in Nepal. BMC Pregnancy Childbirth. 2016;16(1):147. https:// doi.org/10.1186/s12884-016-0938-4

44. World Health Organization. Maternal and neonatal tetanus elimination (MNTE). Geneva: WHO; 2017. Available from: http://www.who.int/ immunization/diseases/MNTE_initiative/en/

45. World Health Organization. WHO recommendations on antenatal care for a positive pregnancy experience. Luxembourg: WHO; 2016. 